\title{
Suomentamisen ideologiat ja normit
}

\author{
Jyrki Kalliokoski, Anne Mäntynen ja Taru Nordlund
}

Kansalaisen huoli kielestä koskee usein kielen köyhtymistä ja vieraan vaikutuksen lisääntymistä sanastossa tai lauserakenteissa. Kielentutkijan rauhoittelevaksi vastaukseksi näihin huoliin on vakiintunut se, että kyse on kielen elämään ja kehitykseen olennaisesti kuuluvista ilmiöistä: variaatiosta ja kielikontakteista. Vaihtelu ja kielten väliset kontaktit ovat asioita, joihin yksittäisen kielenkäyttäjän, kielentutkijan tai kielenhuoltajan valinnoilla ei voi vaikuttaa. Niihin eivät vaikuta myöskään vallanpitäjien toimet kuten lainsäädäntö. Kielipoliittiset päätökset sitä vastoin ovat yhteisöjen, yritysten ja organisaatioiden sekä koko kansankunnan osalta lainsäätäjien käsissä. Keskeinen kielipoliittisten päätösten kohde on eri kielten asema ja käyttöala yhteiskunnassa.

Romantiikan myötä 180o-luku oli Euroopassa kansallisvaltioiden ja kansalliskielten rakentamisen aikaa (Anderson 2007 [1991]; Hobsbawm 1992; ks. myös Huumo, Laitinen \& Paloposki toim. 2004). 1900-luvun lopusta 2000-luvun ensimmäisille vuosikymmenille englannin globaali ylivalta on lähes kaikkialla maailmassa heikentänyt kansallisten kielten asemaa ja kaventanut niiden käyttöalaa. Keskustelu suomen kielen olemuksesta ja siihen liittyvistä kielipoliittisista tavoitteista on Suomessa perinteisesti vilkastunut poliittisten muutosten jälkeen ja yhteisön kielitilanteen muuttuessa. Erityisen selvästi tämä näkyi Suomen suuriruhtinaskunnassa kansallisuusliikkeen nousun ja suomalaistumisen etenemisen myötä 1800 -luvulla. Suomen liityttyä Euroopan unioniin kielipolitiikka ja kotimaisten kielten asema ovat nousseet jälleen esiin.

Tällä vuosituhannella Suomen kielipoliittinen tilanne on muotoutunut uudenlaiseksi. Juuri nyt kielipoliittisen keskustelun yksi pääjuonne on suomen ja englannin työnjako ammatillisessa ja julkisessa kielenkäytössä sekä julkaisemisessa. Tämä aihe on viime aikoina näkynyt myös julkisuudessa, kun lokakuussa 2018 suomen kielen lautakunta otti aiempaa voimakkaammin kantaa kansalliskielten asemaan ja englannin käytön aiheuttamaan uhkaan. Kannanotossaan lautakunta ilmaisi vakavan huolensa suomen ja ruotsin kielten käyttöalojen kaventumisesta ja englannin vakiintumi- 
sesta paitsi työelämän kieleksi myös arkiseksi palvelukieleksi. (Suomen kielen lautakunnan kannanotto 26.10.2018.) Tieteellisen julkaisemisen osalta tilanne näyttää jo nyt useilla aloilla siltä, että englanti on laajalti vakiintunut tutkimuksen kieleksi ja suomen kielen tehtäväksi voi hyvinkin jäädä toimiminen tutkimusta yleistajuistavan tietokirjallisuuden kielenä. Tällainen kehitys rajaisi suomen kielen jälleen sille alueelle, josta 180o-luvulla lähdettiin liikkeelle (Hakulinen ym. 2009; ks. myös Hiidenmaa 2003). Autonomian ajasta lähtien Suomen kansallisen kulttuurin perusehtona on pidetty sekä suomenkielistä tutkimusta - tiedon tuottamista - että sen välittämistä kansalaisille suomeksi. Tässä suomen kielen käyttöalan laajentamistyössä on tietokirjallisuuden suomentamisella ollut merkittävä asema.

Tämä teemanumero kokoaa yhteen tutkimustuloksia Koneen Säätiön rahoittamasta hankkeesta Suomentamisen ideologiat ja normit: tietokirjallisuuden konventioiden muotoutuminen ja keskustelu käännösten kielestä 180o- ja 200o-luvuilla. Hanke koostui kahdesta osahankkeesta, jotka käsittelivät tietokirjallisuuden suomentamisen diskursseja. Molemmissa aihetta lähestyttiin tapaustutkimusten kautta analysoimalla empiirisiä aineistoja. Toisessa osatutkimuksessa tarkasteltiin 200o-luvun tietokirjojen suomennosprosessia, ja toinen kohdistui 180o-luvulle varhaisnykysuomen aikaan, jolloin eri alojen ensimmäiset suomenkieliset tietokirjat syntyivät pitkälti käännöksinä. Tähän teemanumeroon sisältyvissä Mäntysen ja Kalliokosken, Pitkänen-Heikkilän ja Nordlundin artikkeleissa esitellään tieto- ja tiedekirjallisuuden suomennostyössä käytyjä keskusteluja, jotka ilmentävät eri aikakausien käännösprosessien toimijoiden ja yhteisöjen kieli-ideologioita.

Tutkimushankkeen yhteisenä tausta-ajatuksena on ollut kääntämisen tarkastelu prosessina, eli tutkimuskohteena on valmiin käännöstekstin sijaan ollut kääntäminen toimintana. Teoreettisena taustana on toiminut kääntämisen sosiologia ja kääntämisen historiallinen sosiologia, jotka korostavat kääntämisen ja kääntäjien kytköstä ympäröivään yhteiskuntaan ja kulttuuriin. Aika, paikka ja valtasuhteet sekä poliittiset, uskonnolliset ja kulttuuriset käytänteet määrittävät, mitä käännetään, kuka kääntää, miksi, miten ja kenelle. Käännöstoimintaa ohjaavat toisin sanoen kulloisessakin yhteydessä vallitsevat sosiaaliset normit. (Ks. esim. Buzelin 2007; Chesterman 2007; Toury 1995.)

Tietokirjallisuuden suomennostyössä keskeisiä toimijoita ovat kustantamot. Suomessa on toiminut ja toimii useita kustantamoja, jotka kantavat vastuuta suomenkielisestä akateemisesta tietokirjallisuudesta (ks. esim. Strellman 2017). Käytännön työstä niissä vastaavat kustannustoimittajat. 2000-luvun tietokirjallisuuden osalta hankkeen aineistona ovat toimineet tieteellisten tietokirjakäännösten työvaiheessa annetut kommentit sekä kääntäjien ja kustannustoimittajien haastattelut. 180o-luvun käännöstoimintaa on puolestaan tutkittu käymällä läpi kustantajien, tieteellisten seurojen ja muiden arkistojen aineistoja, esimerkiksi eri osapuolien välistä kirjeenvaihtoa, kääntäjien laatimia esipuheita sekä lehdistössä julkaistuja kirja-arvioita ja keskusteluja. Olennaista molemmissa osahankkeissa on ollut se, että kääntäminen nähdään moniäänisenä toimintana (esim. Alvstad, Greenall, Jansen \& Taivalkoski-Shilov toim. 2017), joka tulee kielellistetyksi prosessin eri vaiheissa tuotettuina metatason teksteinä ja kommentteina. 


\section{Normit ja kieli-ideologiat tutkimuskohteena}

Tässä esiteltävän hankkeen tutkimuskohteena ovat olleet suomentamisen ideologiat ja normit. Yhtenä lähtökohtana tutkimuksessa on ollut ajatus, että kaikki kielelliset valinnat ovat ideologisia ja että tutkimalla valintoja voidaan tarkastella myös ideologioita. Ideologialla tarkoitamme arvojen ja uskomusten järjestelmää (Kalliokoski 1996; Thompson 1990; Määttä \& Pietikäinen 2014). Kriittisessä diskurssintutkimuksessa ideologioiden, kielen ja vallan välisten suhteiden keskeisenä ilmenemispaikkana on pidetty tekstejä (esim. Fairclough 2001; Kalliokoski 1996; ks. myös Määttä \& Pietikäinen 2014). Tekstit eivät kuitenkaan yleensä ilmaise ideologioita eksplisiittisesti, vaan ideologisuus pikemminkin säätelee kielellisiä valintoja. Nämä valinnat puolestaan ovat usein luonnollistuneita, "terveen järjen" mukaisia (esim. Fairclough 2001: 69-77). Tavanomainen esimerkki tällaisista valinnoista on kysymys siitä, millä ilmauksella viitataan Suomen vuoden 1918 tapahtumiin (Pietikäinen \& Mäntynen 2009: 57). Kielellisten valintojen ideologisuudessa on kyse siitä, mistä näkökulmasta asioita katsotaan.

Kielenkäyttöä ja kielellisiä valintoja ohjaavat myös yhteisöjen kieltä koskevat ideologiat, kieli-ideologiat. Ne ovat lyhyesti määriteltynä kieltä, kielenkäyttöä ja kielen merkitystä koskevia käsityksiä, ajatuksia ja tuntemuksia (ks. esim. Silverstein 1979; Woolard 1998; Kroskrity 2004, 2010; Mäntynen, Halonen, Pietikäinen \& Solin 2012; Mäntysen ja Kalliokosken sekä Nordlundin artikkelit tässä teemanumerossa). Näkökulmaa rakentavien kielellisten valintojen taustalla on aina kieli-ideologioita, usein myös keskenään ristiriitaisiakin kieltä koskevia käsityksiä, yhteisöllisiä arvoja ja uskomuksia. Kun yksittäinen kielellinen ilmaus kertoo valinnan kautta rakentuvasta, esimerkiksi poliittista kantaa ilmaisevasta näkökulmasta puheena olevaan asiaintilaan, kieli-ideologiat ohjaavat sitä, millä logiikalla ja millaisilla arvoperusteilla valintoja tehdään tietyissä tilanteissa ja miten tietyissä yhteisöissä toimitaan. Myös käännösprosessissa eri toimijoiden (kääntäjä, kustannustoimittaja, asiantuntijalukija) valinnat perustuvat kieltä ja kielenkäyttöä koskeviin käsityksiin, arvoihin ja uskomuksiin - kieli-ideologioihin. Käännösprosessin erityispiirteisiin kuuluu, että käännöksen kielelliset valinnat tehdään myös suhteessa alkuteoksen valintoihin.

Kieli-ideologiat ilmenevät toisaalta konkreettisissa kielenkäyttötilanteissa. Kaikille tuttuja ovat tilanteet, joissa joku osallistujista kommentoi yksittäistä lausumaa: ei noin voi kyllä sanoa. Toisaalta kieli-ideologiat ovat aina historiallisia, ja siksi edellä mainitun toteamuksen voisi tulkita perustuvan esimerkiksi vakiintuneisiin tapoihin suhtautua vieraan kielen vaikutukseen tai käsityksiin yleiskielen ja murteen käyttöaloista. Blommaert (2005) puhuukin kieli-ideologioiden kerrosteisuudesta. Kieli-ideologiat eivät ole henkilökohtaisia vaan yhteisiä, sosiaalisesti jaettuja ja tunnistettavia mutta samalla historiallisesti kerrostuneita; siksi samassa kielenkäyttötilanteessa, kuten jonkin teoksen suomennosprosessissa, voi olla samanaikaisesti läsnä useita, keskenään ristiriitaisiakin kieli-ideologioita (Mäntynen ym. 2012; ks. myös esim. Agha 2007: 292-293).

Kieli-ideologiat vaikuttavat siihen, miten, milloin ja miksi kieli muuttuu. Niiden tutkimus lähtee oletuksesta, että kielenkäyttäjien kielellinen tietoisuus ja käsitys kielestä osana kontekstia muovaavat kieltä ja vaikuttavat kielen muutokseen. Silversteinin (1979: 193) mukaan kieli-ideologiat ovat "sellaisia kielenkäyttäjien julkilausumia usko- 
muksia kielestä, joilla selitetään tai perustellaan havaittuja kielen rakenteen tai käytön piirteitä" (suomennos kirjoittajien).

Kieli-ideologioiden tutkimuksessa analyysi kohdistuu yleensä joko kielenkäyttöön, metakieleen (mitä kielestä sanotaan) tai siihen, miten kieltä säädellään eksplisiittisesti ja implisiittisesti kielenkäyttötilanteissa (Woolard 1998: 9; ks. tarkemmin Mäntynen ym. 2012). Metakielen eli niin sanotun metalingvistisen diskurssin tarkastelussa analysoidaan kielenkäyttäjien puhetta tai tekstiä, jossa puheenaiheena on kieli tai jokin kielenilmiö, kuten ilmaus tai tyyli. Kun tarkastellaan metakielenkäyttöä tai kielen säätelyä käyttötilanteissa, huomio kohdistuu siihen, miten tiettyjen kielellisten valintojen toistaminen vahvistaa ja luonnollistaa normeja ja siten uskomuksia "hyvästä kielestä".

Kuten edellä jo kävi ilmi, kieli-ideologiat ovat aina historiallisia. Niiden taustalla on intertekstuaalisten kytkösten ja tekstilajin sekä tieteenalan kielenkäytön traditio. Kielenkäyttöä koskevat normit perustuvat kieli-ideologioihin, ja yksittäinen normi voi olla tietynlaisen kieli-ideologian ilmentymä. Suomen kirjakielen historian aikana suhtautuminen muiden kielten vaikutukseen on vaihdellut aikakaudesta toiseen. Esimerkiksi 180o-luvun lopusta pitkälle 190o-luvulle torjunnan kohteena oli ruotsin kielen vaikutus suomeen, svetisismit (ks. esim. Nordlund 2004). Vastaavasti suomenruotsin näkökulmasta uhkana pidettiin finlandismeja (af Hällström-Reijonen 2012; Nordlund 2012).

Kieli-ideologian käsite on melko abstrakti, ja joskus yksittäisiä kieli-ideologioita voi olla vaikea yksilöidä ja rajata. Tutkimuksessa niitä on silti nimetty ja on puhuttu esimerkiksi yksi-, kaksi- tai monikielisyyttä korostavasta ideologiasta ja standardikielitai murre-ideologiasta (ks. esim. Milroy \& Milroy 2012; Boudreau \& Dubois 2007). Suomentamisen normeja ja ideologioita käsittelevässä tutkimushankkeessamme tavoitteena on ollut kieli-ideologioiden nimeämisen ja tunnistamisen ohella tutkia sitä, miten erilaiset kieli-ideologiat ja normit tulevat esiin käännösprosesseissa ja miten ne osaltaan ovat rakentamassa käännöstä ja kieltä.

Kieli-ideologioille läheinen käsite on normi. Kieli-ideologiat itsessään eivät ole sääntöjä vaan pikemminkin kulttuurisia järjestelmiä, jotka koskevat kieltä tai kieliä ylipäänsä - eivät vain yksittäisiä ilmauksia tai rakenteita. Kieli-ideologiat ovat normien ja normittamisen perustaa. Normit toisin sanoen perustuvat kieli-ideologioihin. Kielen normittamisen kysymykset nousevat esille erityisesti kirjakielten standardisaatioprosessissa, kun uutta kirjakieltä kehitettäessä kielen normeista on tehtävä yhteisiä sopimuksia. 180o-luvun Suomessa uuden kirjakielen rakentaminen palveli kansallisia pyrkimyksiä: 1500-luvulta lähtien kirjoitettu niin kutsuttu vanha suomi eli pipliasuomi ei täyttänyt kaikkia modernistuvan ja demokraattistuvan yhteiskunnan tarpeita.

Kirjakielen standardisaatioprosessi kytkeytyy suoraan niin kutsuttuun standardikieliideologiaan, oletukseen yhdestä "oikeasta" ja "puhtaasta" kielimuodosta, joka on muiden kielimuotojen, esimerkiksi puhutun kielen, yläpuolella (ks. Milroy \& Milroy 2012; Nordlundin artikkeli tässä teemanumerossa). Tämä perustuu jo romantiikan ajan kieliteoreetikkojen näkemykseen kirjakielestä historiallisen kehityksen huippuna (Rintala 1998). Yhteen yhtenäiseen ja varioimattomaan kirjakieleen on mahdollista päätyä erilaisten normittamisratkaisujen kautta. 180o-luvun Suomessa osa kirjakielen normittajista perusti näkemyksensä vahvasti siihen, että tekeillä olevan kirjakielen tulisi mahdollisimman pitkälti noudattaa kansankieltä ja kirjakieleen tulisi valita vain rakenteita, 
jotka esiintyvät myös puheessa. Kansallisromanttisen ideologian (vrt. Karkama 2007: 84-102) mukaan tähän liittyi usein myös ajatus siitä, että parhaat kielimuodot löytyvät Itä-Suomen murteista, jotka - toisin kuin länsisuomalaiset murteet - ovat välttyneet ruotsin kielen turmelevalta vaikutukselta. Tällaista näkemystä on kutsuttu kansankielisyyskannaksi. Osa normittajista sen sijaan katsoi, että kielen kehittymistä ohjaavat luonnonlakien kaltaiset "evolutiiviset" lait, jotka kielentutkijan on mahdollista löytää kielen tarkan analyysin avulla. Tämän näkemyksen mukaan kirjakielen normien tulisi pohjautua tällaisiin lakeihin eikä esimerkiksi mallinmukaisia analogisia muotoja tulisi hyväksyä (esim. vaikka sanotaan ei aikaakaan, ei tulisi hyväksyä ilmaisua ei hetkeäkään'). Tämä kieliopillisuuskanta kytkeytyy myös niin kutsuttuun etymologiseen kantaan, jonka mukaan kirjakieleen on valittava kielen alkuperäisin ja vähiten muutoksia läpi käynyt muoto. Tällaisten normittamista ohjaavien periaatteiden, kieli-ideologioiden, mukaan suomen kirjakieleen vakiintui 180o-luvun kuluessa muun muassa itäinen geminaatallinen inessiivi (talossa vs. talosa/talos) ja monikon genetiivin alkuaan itäinen monikkovartaloinen muoto (poikien vs. poikain). Yksittäiset kielimiehet eivät yleensä edustaneet puhtaasti mitään tiettyä kantaa, vaan heidänkin näkemyksensä vaihtelivat tilanteen mukaan. (Ks. esim. Laitinen 2004; Lauerma 2004; Nordlund 2004; Paunonen 1992.)

Nykynäkökulmasta kirjakielen normit eroavat toisistaan sekä alkuperältään että velvoittavuudeltaan. Edellä kuvatut 180o-luvun normit ovat normeja, jotka ovat esiintyneet jossakin kielimuodossa jo ennen niiden hyväksymistä kirjakieleen. Rintala (1992: 55) kutsuu tällaisia normeja kirjakieleen otetuiksi normeiksi. Toisen ryhmän muodostavat sellaiset kirjakielelle tehdyt normit, jotka koskevat pelkästään kirjakieltä ja joita luodaan ja muokataan kielenhuoltoelimissä. Tällaisia ovat esimerkiksi kirjakielen lauserakennetta koskevat normit, oikeinkirjoitus tai sanojen merkityksen täsmentäminen ja määrittely. Kolmanneksi normien ryhmäksi Rintala erottaa korrektiiviset normit. Ne poikkeavat hänen mukaansa edellisistä siten, että niiden noudattaminen on jossakin määrin makuasia ja niiden käyttöä voidaan perustella kielen parantamisella: jokin tarjolla olevista vaihtoehdoista voi olla suomalaisempi, kauniimpi tai tarkoituksenmukaisempi kuin muut vaihtoehdot. (Mas. 55-56; ks. myös Mäntysen ja Kalliokosken artikkelia tässä teemanumerossa.)

Kirjakielen normit ovat aina sopimuksenvaraisia ja keinotekoisia. Kielessä on kuitenkin myös luonnollisia normeja, joilla tarkoitetaan jokaisen kielenpuhujan sisäistämää kielitietoa, -taitoja ja -tajua, joiden avulla hänen on mahdollista kommunikoida muiden ihmisten kanssa. Tällaiset normit ovat luonteeltaan sosiaalisia, ja kielenkäyttäjät sosiaalistuvat (tavallisimmin lapsena) niihin omassa kieliyhteisössään. Hyvä esimerkki tällaisesta sosiaalistumisesta on suomen kielen taivutusparadigmojen oppiminen. Suomenkielinen lapsi oppii ympäristöstään sen erityisemmin opettamatta, että esimerkiksi sana lasi taipuu lasi : lasin : lasia mutta lumi-sanaa taivutetaan lumi : lumen : lunta. Hän siis oppii sanojen eri muotoja kuullessaan, että lasi on yksivartaloinen $i$-vartalo mutta lumi kaksivartaloinen $e$-vartalo. Sanaa uuhi 'naaraspuolinen, karitsoinut lammas' ei sen sijaan välttämättä edes jokainen aikuinen suomenkielinen pysty sijoittamaan oikeaan (sanakirjoissa annettuun yleiskielen normien mukaiseen) taivutusparadigmaan, jos sanan

1. August Ahlqvist Kieletär-lehdessä vuonna 1871 (Nordlund 2004). 
käyttö ei ole ennestään tuttua. Sellaisissa yhteisöissä, joissa kielenpuhujien väliset yhteydet eivät ole tiiviitä ja tiheitä, kieliyhteisö ei välttämättä pysty ylläpitämään mutkikkaampia taivutusparadigmoja, kuten konsonanttivartaloisuutta. Tällaisessa tilanteessa sosiaalinen paine ei toisin sanoen enää ole riittävä eikä pidä yllä aiemmin vallinnutta kielen luonnollista normia. Näin on tapahtunut esimerkiksi Norjassa puhuttavassa kveenissä ja Ruotsissa käytettävässä meänkielessä. (Lindgren 1993; Paunonen 2003.)

Kirjakielen ja kielen luonnollisten normien lisäksi kielenkäyttöä säätelevät muunkinlaiset normit, ja normeista voidaan puhua myös tekstilajien tasolla. Tekstilajeja koskeva tietomme ja niihin liittyvät normit ovat intertekstuaalisia: tekstit rakentuvat toisten tekstien pohjalta, ja tunnistamme tekstilajin aiemmin kohtaamiemme tekstien perusteella (Solin 2006: 72). Tekstilajikohtaisia valintoja ohjaavat tekstilajikonventiot, joita voi luonnehtia tekstilajia sääteleviksi normeiksi. Kyse ei ole yksittäisten tekstien suhteesta toisiinsa vaan interdiskursiivisuudesta (Fairclough 1992), saman tekstilajin teksteille yhteisistä piirteistä, tekstien kielellisiä valintoja ja esimerkiksi tekstin rakennetta säätelevistä normeista. (Solin 2006: 74-75; myös Pietikäinen \& Mäntynen 2009: 88-91.) Kääntäjän on tunnettava alkutekstin tekstilajikäytänteet ja toisaalta tunnistettava kohdekielisen kulttuurin vastinetekstilaji. Tähän kuuluu kääntäjän työssä myös diskurssiyhteisön (Swales 199o) ja sen kieltä koskevien käytänteiden ja normien tuntemus ja huomioiminen käännösratkaisuissa: esimerkiksi tieteellisen teoksen ja sen käännöksen lukijoiden voi ajatella kuuluvan samaan diskurssiyhteisöön, saman alan asiantuntijoiden yhteisöön (Rahtu 2011: 23). Tässä mielessä tekstilajit ja niitä koskevat normit ovat siis myös sosiaalisia.

Lisäksi voidaan puhua diskursiivisista normeista. Tällöin normeilla tarkoitetaan sosiaalisista ja diskursiivisista käytänteistä juontuvia yhteisöllisiä sääntöjä, jotka ohjaavat tekemään tiettyjä valintoja ja sulkemaan pois toisia. Diskursiiviset kuten tekstilajejakin koskevat normit ovat kiinteässä yhteydessä kontekstiin ja sosiaaliseen toimintaan, ja ne tulevat usein näkyviin nimenomaan silloin, kun niitä tavalla tai toisella rikotaan. (Pietikäinen \& Mäntynen 2009: 39-40.) Samalla tapaa kielenkäytön normit voivat tulla näkyviin suomennosprosessissa, jossa esimerkiksi käsitteiden kääntämisvaihtoehdot voivat saada erilaisia, jopa epäsopivia merkityksiä tieteenalan, poliittisen tai jonkin muun vakiintuneen diskurssin näkökulmasta (ks. Mäntynen \& Kalliokoski tässä teemanumerossa).

Yksi kääntämisen tutkimisen kannalta merkittävä normittamisen perusta on purismi. Purismi tarkoittaa sellaista kielenhuollon suuntausta, joka pyrkii kielen "puhtauteen" erityisesti karsimalla kielestä vierasperäistä ainesta. Ideologisesti purismi siis perustuu edellä mainittuun standardikieli-ideologiaan. 180o-luvulla purismin kohteena olivat ruotsinmukaisuudet ja kielen normittaminen kytkeytyi kiinteästi myös kansakunnan irrottamiseen vanhasta emämaasta Ruotsista (ks. edelle s. 480). Ilmiönä purismi on kaikkea muuta kuin historiallinen tai nationalismiin kytkeytyvä. Purismi näkyy nykysuomentajien pyrkimyksessä valita suomenkielisiä termejä ja yhtä hyvin tavallisen kansalaisen suhtautumisessa esimerkiksi anglismeihin. ${ }^{2}$ Kielentutkijoiden näkökulmasta huoli ei koske niinkään yksittäisiä sanoja ja sanontoja vaan sitä, voiko

2. Helsingin Sanomien lukijakysely kartoitti suomalaisten suhtautumista anglismeihin. 1260 vastaajasta noin puolet oli huolissaan englannin kielen vaikutuksesta ja puolet suhtautui asiaan neutraalisti. (Aittokoski 2018.) 
suomen kieltä käyttää kaikissa yhteyksissä. Lainasanoja uhkaavampaa on, jos suomi esimerkiksi menettää asemansa tieteen kielenä - aseman, jonka se vasta noin 150 vuotta sitten tietoisen keskustelun ja debattien jälkeen saavutti (Huumo 2005; Hakulinen ym. 2009). Normittamiseen ja purismiin liittyvät kysymykset ovat olleet keskeisiä myös 1800-luvun puolivälistä näihin päiviin saakka kestäneessä siirtomaavallan purkamisessa sekä emansipaatioliikkeissä. Niissä kansallisvaltioiden yksi kieli - yksi kansa -myytin takaa tulee esiin uusia kansallisuus- ja kieliryhmiä, joille oman kielen kehittäminen on mitä ajankohtaisin yhteiskunnallinen kysymys.

Myös kääntämisellä on omat norminsa, jotka vaikuttavat siihen, mitä ja millä periaatteilla ylipäätään käännetään ja millaisia kielellisiä valintoja käännöksissä tehdään. Kääntämisen tutkimuksessa on tapana erottaa kolmenlaisia normeja: ennakkonormit, alkunormit ja toimintanormit (Toury 1995; Chesterman 2007). ${ }^{3}$ Ennakkonormit liittyvät kääntämisen politiikkaan ja säätelevät kääntämisen toimintaa ennakkoon. Ne koskevat sitä, mitä on sopivaa kääntää, kuka saa kääntää ja mitä varten käännöksiä tehdään. Ennakkonormeihin kuuluu myös käsitys siitä, pitääkö käännökset tehdä suoraan alkukielestä vai saako kääntää välikielen kautta. (Chesterman 2007: 359-360; Toury 1995: 53-61.) Ennakkonormit voivat olla jopa kirjoitettuja, jolloin niistä tulee lakeja. Ä̈ritapauksena Chesterman (mas. 359) mainitsee Suomessa vuonna 1850 voimaan tulleen kieliasetuksen, jossa kiellettiin kaunokirjallisuuden julkaisu ja kääntäminen. Ennakkonormien taustalla ovatkin politiikka ja moraalikäsitykset, jotka eivät ole pysyviä vaan muuttuvat siinä missä kulttuuri ja yhteiskuntakin. On kiinnostavaa pohtia, millaiset ennakkonormit tieto- ja tiedekirjallisuuden suomentamisessa nyt vaikuttavat ja ovatko ne mahdollisesti muuttumassa. Esimerkiksi akateemista tiedekirjallisuutta on 200o-luvun alkupuolella edelleen suomennettu runsaasti, joten sille katsotaan olevan tarvetta - vaikka samanaikaisesti juuri akateemisen maailman englanninkielistyminen on aiheuttanut huolta, kuten edellä totesimme.

Alkunormeilla tarkoitetaan kääntämisen tutkimuksessa sitä, millä periaatteilla tekstiä käännetään suhteessa lähde- ja kohdekulttuuriin sekä -kieleen ja kumpaan kääntäjä työssään orientoituu. Alkunormina voi olla mahdollisimman tarkka mutta vieraannuttava käännös tai esimerkiksi käännösratkaisuiltaan vapaampi, kotouttava käännös (Chesterman 2007: 360). Alkunormeilla on lähtökohtaisesti yhteys kieli-ideologioihin riippumatta siitä, orientoituuko kääntäjä (ja esimerkiksi kustannustoimittaja) lähdevai kohdekulttuuriin ja -kieleen. Kuten Chesterman huomauttaa (mp.), "kotouttamisen normiin saattavat liittyä myös ideologiset arvot suomen kielen 'puhtaudesta"'. Hän (mp.) nostaa esiin myös normiauktoriteetit, kuten Suomalaisen Kirjallisuuden Seuran, joka 180o-luvulla tuki, ohjasi ja sääteli käännöstoimintaa - ja vaikutti ennakko- ja alkunormien muotoutumiseen. Chesterman antaa seuraavan esimerkin Suomalaisen Kirjallisuuden Seuran vuosikertomuksesta 1871:

Käännöksen tulee visusti vastata alkuteosta, edellinen ei saa olla jälkimmäistä laimeampi eikä liioin väkevämpi, ei saa hapuillen mukailla eikä kiertelemällä suotta

3. Kääntämisen tutkimuksessa on jäsennetty normeja myös muilla tavoin (tarkemmin Chesterman 2007: 361 lähteineen). 
tästä poikkeilla, mutta ei myöskään siinä orjallisesti riippua kiinni, ei vierasta kieltä valuttaa oman kielen sanoilla. - - Käännöksen tulee olla lausekeinonsa eli styylinsä puolesta jotakin erinomaista, sopikoon malliksi, kelvatkoon esikuvaksi. (Chesterman 2007: 361.)

Touryn (1995) erottamista normityypeistä kolmas on toimintanormit, jotka ohjaavat kääntäjän päätöksiä käännösprosessissa. Toimintanormit koskevat esimerkiksi alaviitteiden käyttöä, tekstinosien tai ilmausten poistoja, lisäyksiä ja selityksiä sekä tyylillisiä ratkaisuja ja kielimuotojen, kuten murteen, käyttöä (Chesterman 2007: 361). Hankkeemme kannalta tärkeitä ovat käsitteiden kääntämistä ja selittämistä sekä tieteellisiä, alakohtaisia diskursseja ja tiedesanastoa koskevat toimintanormit, joita käsittelevät Mäntysen ja Kalliokosken sekä Pitkänen-Heikkilän artikkelit tässä teemanumerossa (ks. myös Pitkänen-Heikkilä 2010a). Kieli-ideologian tutkimuksen näkökulmasta Touryn toimintanormit voi nähdä kieli-ideologisina käytänteinä kuten kääntämisen normit yleisemminkin (Mäntynen 2012: 384).

Käännöksen muotoutumiseen vaikuttavat normit voivat painottua eri käännösprosesseissa eri tavoin. Kääntäminen ja käännösnormit ovat oman aikansa kulttuuristen normien ja kulttuuristen muutosten armoilla, ja tästä syystä kääntämisen ja sen normien historian tutkimus tuottaa tietoa paitsi käännöksistä myös niistä yhteisöistä, instituutioista ja ajankohdista, joissa ne ovat syntyneet. Chesterman (2007: 357) toteaa tästä seuraavasti: "Erityisen kiinnostavia ovat käännökset tai aikakaudet, joissa ilmenee normien muutoksia. Tällainen muutos voi paljastaa jotain yhteiskunnan tai arvomaailman yleisemmästä kehityksestä.” (Mp.)

Suomentamisen ideologiat ja normit -hankkeessa tutkimuksen näkökulma on kohdistettu käännetyn tieto- ja tiedekirjallisuuden diskursseihin kahtena kielipoliittisesti merkittävänä ajankohtana. Näin avautuu perspektiivi metatason keskusteluun hyvästä suomen kielestä ja suomenkielisen asiaproosan normeista. Kielentutkimuksen keinoin on voitu tutkia esimerkiksi ajan kieli-ihanteiden suhdetta toisaalta käännösten lähtökieliin ja niiden rakenteissa kiteytyviin kielellisiin merkityksiin, toisaalta tietenkin kääntäjän kielellisiin valintoihin. Samalla on tarkasteltu kuitenkin myös sitä erilaisten kielellisten ideologioiden välistä neuvottelua, jota käännösprosessiin osallistuvat eri alojen asiantuntijat käyvät keskenään.

\section{Tietokirjallisuuden ja sen kääntämisen tutkimuksesta}

Tietokirjallisuutta, sen kieltä ja historiaa käsitteleviä isoja tutkimushankkeita on ollut Pohjoismaissa 1990-luvun lopulla sekä vielä erikseen 200o-luvun alussa Ruotsissa (ks. Svensk sakprosa 1750-2000) ja Norjassa (ks. Forskningsmiljøet Norsk sakprosa). Suomessa tällaista tutkimusta on tehty melko vähän. Parhaillaan on kuitenkin Helsingin yliopistossa meneillään tietokirjallisuuden narratiivisuuteen keskittyvä Tiedonkerrontahanke (https://blogs.helsinki.fi/tietokirjallista/). Tässä teemanumerossa esiteltävien tutkimusten kannalta erityisen tärkeitä ovat vuonna 2007 ilmestynyt Suomennoskirjallisuuden historia 1-2 (Riikonen, Kovala, Kujamäki \& Paloposki toim. 2007), joka 
käsittelee kääntämisen muuttumista, normeja ja strategioita eri aikoina, sekä teos Suomennetun tietokirjallisuuden historia 180o-luvulta 200o-luvulle (Paloposki \& Riikonen toim. 2013). Tietokirjallisuuden suomentamista tarkastellaan myös Suomalaisen Kirjallisuuden Seuran historiaa käsittelevässä teossarjassa (Sulkunen 2004; Häggman 2012, 2015). Käännössuomea on puolestaan tutkittu laajassa hankkeessa korpustutkimuksen metodein. Tässä projektissa osa aineistosta edustaa tietokirjallisuutta (mm. erilaisia oppaita) ja analyysi on keskittynyt kääntämisen tuloksena syntyneen kielen piirteisiin, ei suomentamisen prosessiin ja ideologioihin (ks. esim. Mauranen \& Jantunen toim. 2005). Myös käännösprosessia on tutkittu mutta nimenomaan kääntäjä(yksilö)n työn kannalta - ei siis kääntämisen sosiaalisena prosessina, vuorovaikutuksena alan toimijoiden kesken (ks. kuitenkin Päivärinne 2018). Käännösprosessin aikana käytyjä keskusteluita tai käännösversioiden kommentointia ei ole juuri tarkasteltu.

Suomen kirjakielen historian valossa tietokirjoja on sivunnut eri yhteyksissä Häkkinen, joka on julkaissut myös suomalaisen oppikirjan historian (Häkkinen 2002). Suomen kielen oppikirjojen historiaa on kartoittanut myös Vehkanen (2015). Nykysuomen kirjakielen rakentamista 1800 -luvulla selvitelleen monitieteisen tutkimushankkeen piiristä (ks. Huumo, Laitinen \& Paloposki toim. 2004) on valmistunut väitöskirjoja suomentamisen historiasta (Paloposki 2002), tieteen kielestä (Huumo 2005) ja kirjahistorian alalta (Hakapää 2008) sekä suomen kielen gradutöitä ja muita tutkielmia. Hankkeessa tarkasteltiin myös 180o-luvun kielellisiä ideologioita, joita samoihin aikoihin lähestyi sanaston kannalta yhteiskuntatieteilijöiden tutkimushanke Käsitteet liikkeessä (ks. Hyvärinen, Kurunmäki, Palonen, Pulkkinen \& Stenius 2003).

\section{Suomennosprosessit 2000- ja 1800-luvuilla}

Suomennoksiin tai niiden historiaan ei ole toistaiseksi juuri sovellettu diskurssintutkimuksen näkökulmaa, eikä kielellisten normien ja ideologian välinen suhde ole erityisesti ollut suomennosten tutkijoiden kohteena. Tutkimushankkeessa Suomentamisen ideologiat ja normit tarkastelun kohteena ovat olleet seuraavat kysymykset:

- Miten tietokirjallisuuden suomennokset ja suomentamisen konventiot syntyvät?

- Millaisia keskusteluja suomennosten kielestä ja kielellisistä ratkaisuista käytiin 1800-luvulla ja käydään 200o-luvulla?

- Miksi ja miten suomennoksista käytävä keskustelu liittyy laajempaan keskusteluun kielestä, normeista ja kieli-ideologioista?

Hankkeen työryhmään ovat kuuluneet Jyrki Kalliokoski, Petri Lauerma, Lea Laitinen, Anne Mäntynen ja Taru Nordlund sekä sittemmin Kaarina Pitkänen-Heikkilä. Hankkeessa on tarkasteltu tietokirjallisuuden suomentamisen diskursseja ja kieliideologioiden rakentumista suomennostyössä 1800- ja 2000-luvuilla. Tutkimusaihetta on lähestytty tapaustutkimusten kautta analysoimalla empiirisiä aineistoja. Kuten edellä kävi ilmi, tutkimushanke on koostunut kahdesta osahankkeesta, joissa on käsitelty tietokirjallisuuden suomentamisen diskursseja ja kieli-ideologioiden rakentu- 
mista suomennostyössä. Esittelemme näitä osahankkeita alaluvuissa 3.1 ja 3.2, minkä jälkeen johdatamme teemanumeron artikkeleihin (alaluku 3.3).

\subsection{Asiantuntijuuksien ja normien suhde 2000-luvun tietokirjallisuuden käännöksissä}

Tässä osahankkeessa tutkimuksen kohteena on ollut akateemisen tietokirjallisuuden - tai tiedekirjallisuuden - suomennosprosessi 200o-luvun alkupuolella. Tarkasteltavia suomennosprosesseja leimaa se, että akateemisen tietokirjallisuuden suomentamiseen osallistuu usein kolmenlaisia asiantuntijoita: kääntäjiä, asiantuntijalukijoita ja kustannustoimittajia (ks. tarkemmin Mäntynen 2013; myös Mäntynen 2012). Erityisenä kiinnostuksen kohteena on ollut näiden toimijoiden kielestä ja kielellisistä valinnoista käymä keskustelu, jossa kielen ja hyvän tyylin normeja rakennetaan ja jossa niistä neuvotellaan. Tämä neuvottelu ei välttämättä näy suoranaisena puheena tai keskusteluna vaan pikemmin erilaisina korjausten ja kommentoivan diskurssin ristiriitaisuuksina suomennosprosessissa.

Tutkimusaineistona on ollut humanistis-yhteiskuntatieteellisten akateemisten tietoteosten käännösversioita kommentteineen sekä näiden teosten kääntäjien, kustannustoimittajien ja sisällön asiantuntijoiden haastatteluja. Aineisto on koostunut teoksista, jotka on julkaistu akateemisten tutkijoiden ja opiskelijoiden käyttöön ja joiden julkaisuprosessiin on osallistunut tieteenalan asiantuntija. Lisäksi hankkeessa on haastateltu eri toimijoita, erityisesti kääntäjiä.

Tarkastelun kohteena olevat kieli-ihanteet ja normit tulevat näkyviin tietenkin suomentajan tekemissä korjauksissa mutta lisäksi mahdollisen sisällön asiantuntijan ja kustannustoimittajan korjauksissa ja kommenteissa. Kaikki kolme toimijaa ovat siis prosessissa oleellisia. Toimijoiden asiantuntijuudet ovat usein moniulotteisia: Ensinnäkin suomennoksia tekevät sekä ammattikääntäjät että akateemiset asiantuntijat, joista erityisesti jälkimmäiset ovat myös sisällön asiantuntijoita. Toiseksi suomennosversioita lukevat ja kommentoivat suomennosprosessin aikana sisällön asiantuntijat. He ovat usein sen akateemisen oppialan asiantuntijoita, johon tekstin katsotaan kuuluvan. He kuitenkin kommentoivat toisinaan myös kieltä, etenkin oppialan diskurssien näkökulmasta. Kolmanneksi käännöksiä lukevat, korjaavat ja kommentoivat kustannustoimittajat, joilla voi olla tietyn alan akateeminen koulutus. Kun osa sisältöasiantuntijoidenkin kommenteista kohdistuu kieleen ja tyyliin eikä kielen asiantuntijuutta voi irrottaa sisällöstä, eri toimijoiden asiantuntijuudet väistämättä limittyvät.

Analyysin kohteena ovat olleet teksteihin suomennosprosessin eri vaiheissa tehdyt kieltä ja tyyliä koskevat kommentit ja korjausehdotukset (ks. Mäntynen 2012; Mäntynen \& Kalliokoski tässä teemanumerossa). Asiantuntijuuksien kamppailua ja neuvottelua on tarkasteltu diskurssin ristiriitaisuuksina ja moniäänisyytenä, joita on analysoitu sekä suomennosprosessissa ilmenevistä kommenteista ja korjausehdotuksista että haastattelemalla prosessiin osallistuvia toimijoita (kääntäjiä, asiantuntijalukijoita ja kustannustoimittajia). Ilmiöiden tarkastelussa on liikuttu kolmella kielentutkimuksen osa-alueella: kielen normien ja kieli-ideologioiden tutkimuksessa, kääntämisen tutkimuksessa ja diskurssintutkimuksessa (tuottamisprosessien ja metakielen tutkimus). Tutkimusmenetelmät ovat perustuneet diskurssianalyysiin ja kirjoittamisen sosiolingvistiikkaan. 


\subsection{Kielen ja kääntämisen normit ja ideologiat 1800-luvun Suomessa}

180o-luvulla suomen kirjakielen kehittämisen ja vakiinnuttamisen keskeisenä tavoitteena oli kansalliskirjallisuuden rakentaminen, ja siinä suomennetulla kauno- ja tietokirjallisuudella oli tärkeä rooli. Malleja suomenkieliselle tietokirjallisuudelle ei ollut; sille rakennettiin perustaa erityisesti eri alojen oppikirjoja ja opaskirjallisuutta suomentamalla. Tietokirjallisuus oli aluksi pitkään kansanvalistusta, joka jatkui sitten oppikirjatuotantona. Koululaitosta koskevien kielipoliittisten päätösten vuoksi paine suomentamiseen oli valtava. Vuosisadan puolivälistä lähtien työhön ryhtyi kansallismielinen sivistyneistö ympäri maata.

Koska 180o-luvulla kirjakielen muotoratkaisut ja sanasto olivat vasta kehittymässä, suomentajien työ oli erilaista kuin nyt. He loivat standardikieltä toisessa mielessä kuin nykyajan tietokirjasuomentajat - siitäkin huolimatta, että monet olivat kielenvaihtajia, jotka vasta opettelivat suomea. Esimerkiksi Schrödlerin fysiikan oppikirjan (Luonnonkirja, kotona ja kouluissa luettava, 1856) suomentaja Innain totesi teoksen esipuheessa:

Tämä on ihan ensimmäinen kaikkien merkillisempien physikillisten ilmausten suomenkielinen selitys. Suomen kieli on tässä ollut taivutettava asioihin, joissa sitä ei ole ollenkaan käytetty tätä ennen, ja arvattava on ei ainoastaan, että tämä taivuttaminen on ollut työlästä, vaan myös, että se ei ole voinut kaikin paikoin onnistua mieltä myöten. Sentähden voipi moni kohta vielä olla lukijalleki työlästä ymmärtää, vaikka Kirjallisuuden Seuran erinomaisena tarkoituksena ja huolena on ollut, saada kirjaa kielensä puolesta kaikille Suomalaisille selkiäksi.

Oppikirjojen suomentaminen tarkoitti käytännössä valtavaa projektia, jossa eri alojen tieteellisille käsitteille piti laatia suomenkielinen termistö. Terminologian kehittämistä ohjasivat osin vastakkaisetkin ideologiat: yhtäältä pyrittiin laatimaan omaperäiseen sanastoon pohjautuvia ja suomenkieliselle väestölle läpinäkyviä termejä ja toisaalta pidettiin tärkeänä käyttää jo muihin eurooppalaisiin kieliin ja tieteeseen vakiintuneita ja oppineille ennestään tuttuja kreikkalais- tai latinalaisperäisiä ilmauksia.

180o-luvulla kustantaja oli aktiivisesti mukana suomennosten kielen suunnittelussa. Kustantajan ja suomentajan välinen linkki oli tuohon aikaan vahva siksikin, että juuri tieteelliset seurat toimivat usein kustantajina ja niiden jäsenet tietokirjallisuuden suomentajina. 180o-luvun lopussa perustettiin Suomen ensimmäiset kaupalliset kustantamot. Samaan aikaan kääntäminen alkoi ammattimaistua, kun se aiemmin oli ollut opettajien, pappien, lääkäreiden, tutkijoiden, toimittajien ja muiden sivistyneistöön kuuluvien henkilöiden valistus- ja kansallishenkistä oheistoimintaa. 180o-luvun lopulla suomentajat olivat kielitaitoinen ja -tietoinen joukko, joka oli hyvin perillä muutoksessa olevista kirjakielen normeista. Tämä näkyy esimerkiksi kustantajien ja kääntäjien välisessä kirjeenvaihdossa tai kääntäjien laatimissa teosten esipuheissa. Suomentajat seurasivat kielen normeista käytävää keskustelua ja osallistuivat omalta osaltaan myös normien vakiinnuttamiseen.

180o-luvun suomentamisen tutkiminen on alkanut arkistotyöllä ja tutkimusaineistojen kartoittamisella. Tutkimusmateriaalia on löytynyt muun muassa kustanta- 
moiden ja suomentajien arkistoista ja kirjallisista jäämistöistä, Kansallisarkistosta, maakunta-arkistoista, yliopistojen arkistoista ja Suomalaisen Kirjallisuuden Seuran arkistosta. Joskus materiaalin löytyminen on ollut työlästä. Esimerkiksi suomennosten painamattomia käsikirjoituksia on ilmeisesti vain harvoin arkistoitu painetun teoksen julkaisemisen jälkeen. Arkistomateriaalin lisäksi 180o-luvun suomentamisen prosessia on voinut tarkastella myös lehdistöstä. Suomennosten kielestä puhuttiin säännöllisesti esimerkiksi Kirjallisen Kuukauslehden, Valvojan ja Virittäjän tietokirja-arvioissa. Toisin kuin nykyisin kielen arviointi oli usein kirja-arvostelujen pääsisältönä. Aikakaus- ja sanomalehdissä käytiin myös yleisökeskustelua tietokirjojen kielestä. Käännösratkaisuja ja niiden takana olevia perusteluja ja ideologioita valaisevat myös suomentajien itse teoksiinsa laatimat esipuheet ja teoksissa esiintyvät selittävät alaviitteet. (Ks. Pitkänen-Heikkilä 201ob.)

Aineistojen tutkimusmetodina on ollut lingvistinen tekstintutkimus, jonka keinoin on analysoitu 180o-luvun tietokirjallisuuden suomennosdiskurssien kielellisiä ideologioita ja pyritty ymmärtämään niistä seuranneita ratkaisuja.

\subsection{Teemanumeron artikkelit}

Tässä numerossa julkaistaan kolme Suomentamisen ideologiat ja normit -hankkeessa syntynyttä artikkelia. Ensimmäinen niistä käsittelee yhden tiedekirjan suomennosprosessia, joka ajoittui 200o-luvun alkuun. Tässä Mäntysen ja Kalliokosken artikkelissa tarkastellaan kääntäjän ja kustannustoimittajan välistä keskustelua käsitteiden käytöstä. Aineistona on yhden käännöksen käsikirjoitus, johon kääntäjän ja kustannustoimittajan välistä keskustelua on kirjattu. Keskustelu on syntynyt siten, että kääntäjä on kirjallisesti vastannut kustannustoimittajan kommentteihin muun muassa selventääkseen ja perustellakseen, miksi on samaa tai eri mieltä kustannustoimittajan ehdotuksen kanssa. Artikkelissa pyritään jäsentämään kieli-ideologian käsitteen avulla käsikirjoitusmerkintöihin kirjattua suomentajan ja kustannustoimittajan välistä kielellisiä valintoja koskevaa dialogia. Analyysi keskittyy suomennoksen sananvalintoihin, tarkemmin tieteenalan ja käännettävän teoksen aiheen kannalta keskeisiksi tai muuten pulmallisiksi havaittujen käsitteiden ja termien käännöksistä käytyyn keskusteluun. Artikkeli osoittaa, että kun tutkitun käännösprosessin toimijat perustelevat kielellisiä valintojaan (suomennoksia, muutosehdotuksia), he nojaavat argumentoinnissaan toisaalta puristisiin, vieraan kielen vaikutusta torjuviin kieli-ideologisiin käsityksiin, mutta vetoavat myös toisaalta käsityksiin siitä, mikä kuuluu tieteenalan kielenkäyttöön ja mikä ei. Suhtautuminen monikielisyyteen ja siihen, onko lähtökielen vaikutus suomennokseen hyväksyttävää ja missä määrin, nousee suomennosprosessissa esiin toistuvasti. Kiinnostavaa on se, että esimerkiksi saman toimijan suhtautuminen vierasperäisiin ilmauksiin suomennosvastineina vaihtelee kommenteittain. Artikkelin esimerkkien analyyseistä käy ilmi kieliideologioiden kerrostuneisuus ja keskinäinen ristiriitaisuus.

Pitkänen-Heikkilän artikkeli taas käsittelee tiedesanaston suomentamista koskevia normeja pääosin 180o-luvun luonnontieteellisissä tietokirjoissa mutta tekee katsauksen myös tämän päivän sanastotyöhön. Kääntäjien sanastonkehittelyn tarkastelun ohella artikkeli käsittelee tietokirjoissa käytetyn tiedesanaston herättämää keskustelua teosten vastaanoton yhteydessä ja pyrkii valottamaan myös sellaisia sanastonkehittelyn peri- 
aatteita, joita kääntäjät tai kirjoittajat itse ilmaisivat muun muassa esipuheissa, kirjeenvaihdossa, arvioiden vastineissa ja itse laatimissaan teosarvioissa. Artikkeli ottaa 180oluvun sanastoprojektin vertailukohdaksi 200o-luvun alun laajan nisäkäsnimistön uudistuksen ja sitä seuranneen keskustelun. Näin se samalla tuo esiin ne sanastonkehittelyn puolet, jotka ajasta riippumatta näyttävät puhuttavan kielenkäyttäjiä.

Nordlundin artikkeli vuorostaan käsittelee tietokirjojen suomentamiseen liittyviä ideologioita ja käännösnormeja 180o-luvun tietokirjallisuudessa. Tämä tapaustutkimus kohdistuu Werner Söderström Osakeyhtiön tietokirjojen suomennostoimintaan 1800luvun lopulla. Artikkeli pohtii kääntämisen historiallisen sosiologian näkökulmasta myös sitä, miten ja missä määrin historiallisia käännösprosesseja voidaan rekonstruoida ja millaisia toimijoita käännösprosessiin 180o-luvulla osallistui. Pääasiallisena tutkimusaineistona on kustantajan ja kääntäjien välinen kirjeenvaihto.

Nordlundin tutkimus osoittaa, että 180o-luvun lopulla kääntäjät ja kustantaja jakoivat yhteisen ideologisen käsityksen siitä, että on olemassa oikea, puhdas ja monoliittinen ideaalikieli, johon suomennoksessa tuli pyrkiä. Vastaavanlainen niin kutsutun standardikieli-ideologian mukainen näkemys avautuu myös aikakauden julkisista debateista ja kirja-arvioista. Kirjeaineisto paljastaa julkisuuden verhon takaa kuitenkin myös kääntäjän arkitodellisuuden, johon kuuluivat kiire, pienet palkkiot ja kompromissit ihanteiden ja todellisuuden välillä. Tutkimus osoittaa lisäksi, että vastaanottajan huomioon ottaminen on ollut tietoinen suomentamista ohjaava käännösnormi: tavalliselle kansalle tarkoitetut suomennokset poikkesivat joiltakin osin oppineille tarkoitetuista teksteistä.

\section{Lähteet}

Agha, Asif 2007: Language and social relations. Cambridge: Cambridge University Press. Аіттококкі, Hегккі 2018: "Dinnerille öbaut kasilta?" - Anglismien tunkeutumista suomen kieleen ei voi estää, mutta ne ylittävät monen ärsytyskynnyksen, selviää HS:n kyselystä. - Helsingin Sanomat 16.11.2018. https://www.hs.fi/ulkomaat/art-2000005901215.html (4.12.2018).

Alvstad, Cecilia - Greenall, Annjo K. - Jansen, Hanne - Taivalkoski-Shilov, KRISTIINA (toim.) 2017: Textual and contextual voices of translation. Amsterdam: John Benjamins.

Anderson, Benedict 2007 [1991]: Kuvitellut yhteisöt. Nationalismin alkuperän ja leviämisen tarkastelua. Suomentanut Joel Kuortti. Tampere: Vastapaino.

Blommaert, Jan 2005: Discourse. A critical introduction. Cambridge: Cambridge University Press.

Boudreau, Annette - Dubois, Lise 2007: Français, Acadien, Acadjonne. Competing discourses on language preservation along the shores of the Baie Sainte-Marie. - Alexandre Duchêne \& Monica Heller (toim.), Discourses of endangerment. Interest and ideology in the defense of languages s. 99-121. London: Continuum International.

BuZelin, HÉLÈne 2007: Translation studies, ethnography and the production of knowledge. - Paul St-Pierre \& Prafulla C. Kar (toim.), Translation. Reflections, refractions, transformations s. 39-56. Amsterdam: John Benjamins.

Chesterman, Andrew 2007: Kääntämisen normit. - H. K. Riikonen, Urpo Kovala, Pekka 
Kujamäki \& Outi Paloposki (toim.), Suomennoskirjallisuuden historia 2 s. 357-364. Helsinki: Suomalaisen Kirjallisuuden Seura.

Fairclough, Norman 1992: Discourse and social change. Cambridge: Polity Press.

2001: Language and power. Toinen painos. London: Longman.

Forskningsmiljøet Norsk sakprosa. http://sakprosasiden.no (9.11.2018).

HAKA P̈̈̈̈, Jy RKI 2008: Kirjan tie lukijalle. Kirjakauppojen vakiintuminen Suomessa 1740-1860. Helsinki: Suomalaisen Kirjallisuuden Seura.

Hakulinen, Auli - Kalliokoski, Jyrki - KankaAnpä̈̈, Salli - Kanner, Antti Koskenniemi, Kimmo - Laitinen, Lea - MaAmies, SARi - Nuolijärvi, Pirkko 2009: Suomen kielen tulevaisuus. Kielipolittinen toimintaohjelma. Helsinki: Kotimaisten kielten tutkimuskeskus. http://scripta.kotus.fi/www/verkkojulkaisut/julk7/.

HiddenmaA, Pirjo 2003: Suomen kieli - who cares? Helsinki: Otava.

Нов B AW M, ERIC 1992: Nations and nationalism since 1780. Programme, myth, reality. Cambridge: Cambridge University Press.

Huumo, Katja 2005: Perkeleen kieli. Suomen kieli ja poliittisesti korrekti tiede 180o-luvulla. Helsinki: Suomalaisen Kirjallisuuden Seura.

Huumo, Katja - Laitinen, Lea - Paloposki, Outi (toim.) 2004: Yhteistä kieltä tekemässä. Näkökulmia suomen kirjakielen kehitykseen 180o-luvulla. Bidrag till kännedom av Finlands natur och folk. Helsinki: Suomen Tiedeseura.

Hyvärinen, Matti - Kurunmäki, Jussi - Palonen, Kari - Pulkkinen, Tuija Stenius, Henrik 2003: Käsitteet liikkeessä. Suomen poliittisen kulttuurin käsitehistoria. Tampere: Vastapaino.

Häggman, Ka I 2012: Sanojen talossa. Suomalaisen Kirjallisuuden Seura 189o-luvulta talvisotaan. Helsinki: Suomalaisen Kirjallisuuden Seura.

_ 2015: Pieni kansa, pitkä muisti. Suomalaisen Kirjallisuuden Seura talvisodasta 20oo-luvulle. Helsinki: Suomalaisen Kirjallisuuden Seura.

HäKKInEN, KAISA 2002: Suomalaisen oppikirjan vaiheita. Helsinki: Suomen tietokirjailijat.

Hällström-Reijonen, ChARLOtTA AF 2012: Finlandismer och språkvård från 18oo-talet till $i$ dag. Nordica Helsingiensia 28. Helsingfors: Helsingfors universitet.

KAlliokoski, Jyrki 1996: Johdanto. - Jyrki Kalliokoski (toim.), Teksti ja ideologia. Kieli ja valta julkisessa kielenkäytössä s. 8-36. Kieli 9. Helsinki: Helsingin yliopiston suomen kielen laitos.

Karkama, Pert ti 2007: Kadonnutta ihmisyyttä etsimässä. Johdatusta Johann Gottfried Herderin ajatteluun ja herderiläisyyteen Suomessa. Helsinki: Suomalaisen Kirjallisuuden Seura.

Kroskrity, Paul V. 2004: Language ideologies. - Alessandro Duranti (toim.), A companion to linguistic anthropology s. 496-517. Malden, MA: Blackwell.

2010: Language ideologies. Evolving perspectives. - Jürgen Jaspers, Jan-Ola Östman \& Jef Verschueren (toim.), Society and language use s. 192-211. Amsterdam: John Benjamins.

Laitinen, LeA 2004: Kieltosana ja kieletär. Yhden kielikiistan kulku ja ideologiat. - Katja Huumo, Lea Laitinen \& Outi Paloposki (toim.), Yhteistä kieltä tekemässä. Näkökulmia suomen kirjakielen kehitykseen 180o-luvulla s. 177-222. Helsinki: Suomalaisen Kirjallisuuden Seura.

Lauerma, Petri 2004: Aluemurre vai murteiden yhdistelmä? Keskustelu kirjakielen perustasta 180o-luvun alkupuolella. - Katja Huumo, Lea Laitinen \& Outi Paloposki (toim.), Yhteistä kieltä tekemässä. Näkökulmia suomen kirjakielen kehitykseen 18oo-luvulla s. 136-176. Helsinki: Suomalaisen Kirjallisuuden Seura.

Lindgren, AnnA-Ritt ta 1993: Miten muodot muuttuvat? Ruijan murteen verbintaivutus Raisin, Pyssyjoen ja Annijoen kveeniyhteisöissä. Tromssa: Tromssan yliopiston kielten ja kirjallisuuden laitos. 
Mauranen, Anna - Jantunen, Jarmo H. (toim.) 2005: Kä̈nnössuomeksi. Tutkimuksia suomennosten kielestä. Tampere Studies in Language, Translation and Culture A1. Tampere: Tampere University Press.

Milroy, James - Milroy, Leslie 2012: Authority in language. Investigating standard English. Lontoo: Routledge.

Mäntynen, Anne 2012: Kieli-ideologiat käytännössä. Sanajärjestyksen normittuminen tietokirjojen suomennostyössä. - Virittäjä 116 s. 378-409.

2013: Akateemisen tietokirjallisuuden suomennosprosessin erityispiirteitä. - Outi Paloposki \& H. K. Riikonen (toim.), Suomennetun tietokirjallisuuden historia 18oo-luvulta 20oo-luvulle s. 322. Helsinki: Suomalaisen Kirjallisuuden Seura.

Mäntynen, Anne - Halonen, Mia - Pietikäinen, Sari - Solin, Anna 2012: Kieliideologioiden teoriaa ja käytäntöä. - Virittäjä 116 s. 325-348.

Mä̈̈тtä, Simo K. - Pietikäinen, Sari 2014: Ideology. - Jan-Ola Östman \& Jef Verschueren (toim.), Handbook of pragmatics. 2014 Installment. Amsterdam: John Benjamins. https://doi.org/10.1075/hop.18.ide1.

NORDLUnd, TARU 2004: Arat taimet ja ankarat puutarhurit. 1800-luvun lopun kielikeskustelun metaforat ja kieli-ideologiat. - Katja Huumo, Lea Laitinen \& Outi Paloposki (toim.), Yhteistä kieltä tekemässä. Näkökulmia suomen kirjakielen kehitykseen 18oo-luvulla s. 286-322. Helsinki: Suomalaisen Kirjallisuuden Seura.

- 2012: Finlandismit ja suomenruotsin kielenhuolto 180o-luvulta nykypäivään. - Virittäjä 116 s. $464-470$.

PALOPOSKI, OUTI 2002: Variation in translation. Literary translation into Finnish 1809-1850. Helsinki: Helsingin yliopisto.

Paloposki, OUti - Riikonen, H. K. (toim.) 2013: Suomennetun tietokirjallisuuden historia 180o-luvulta 200o-luvulle. Helsinki: Suomalaisen Kirjallisuuden Seura.

Paunonen, Heıк к 1992: Kielettären koulijat. - Valma Yli-Vakkuri, Maija Länsimäki \& Aarre Nyman (toim.), Yhteiskunta muuttuu - kieli muuttuu. Nykysuomen seuran 1o-vuotisjuhlakirja s. 150-175. Helsinki: WSOY.

2003: Suomen kielen morfologisista muutosmekanismeista. - Lea Laitinen, Hanna Lappalainen, Päivi Markkola \& Johanna Vaattovaara (toim.), Muotojen mieli. Kirjoituksia morfologiasta ja variaatiosta s. 187-248. Kieli 15. Helsinki: Helsingin yliopiston suomen kielen laitos.

Pietikäinen, Sari - Mäntynen, Anne 2009: Kurssi kohti diskurssia. Tampere: Vastapaino.

PitkëNEN-HeIKKILÄ, KAARINA 2010a: Suomentaja normien ylläpitäjänä ja rakentajana. Johan Bäckvall ja Topeliuksen Luonnon-kirjan suomennosprosessi. - Sirkka Saarinen, Kirsti Siitonen \& Tanja Vaittinen (toim.), Sanoista kirjakieliin. Juhlakirja Kaisa Häkkiselle 17. marraskuuta 2010 s. 81-95. Suomalais-Ugrilaisen Seuran Toimituksia 259. Helsinki: Suomalais-Ugrilainen Seura.

- 2010b: Miten 180o-luvun tietokirjojen suomentamisprosessia voi tutkia? - Raila Hekkanen, Esa Penttilä \& Nestori Siponkoski (toim.), MikaEL. Kääntämisen ja tulkkauksen tutkimuksen verkkojulkaisu. https://sktl-fi-bin.directo.fi/@Bin/25dd513ffab4a39d8588678b4 4doc872/1544455422/application/pdf/40743/Pitkanen-Heikkila_MikaEL2O1O.pdf.

PÄIVÄrinne, MERI 2018: Jean Barbeyrac, traducteur et homme de lettres. Helsinki: Helsingin yliopisto. http://urn.fi/URN:ISBN:978-951-51-4232-o.

RAнtu, Toın i 2011: Tekstilaji on työkalu. - Leena Immonen, Mari Pakkala-Weckström \& Inkeri Vehmas-Lehto (toim.), Kääntämisen tekstilajit ja tekstilajien kääntäminen s. 11-28. Helsinki: Finn Lectura.

Riikonen, H. K. - Kovala, Urpo - Kujamäki, Pekka - Paloposki, Outi (toim.) 
2007: Suomennoskirjallisuuden historia 1-2. Helsinki: Suomalaisen Kirjallisuuden Seura.

Rintala, Päıvi 1992: Suomen kirjakielen normeista. - Sananjalka 34 s. 47-67.

— 1998: Kielikäsitys ja kielenohjailu. - Sananjalka 40 s. 47-65.

SChöDler, F. 1856: Luonnonkirja, kotona ja kouluissa luettava. I:nen Osa. Physikki .Suomentanut J. Innain. Viipuri: Suomalaisen Kirjallisuuden Seura. - [Tekstikorpus.] Sisältyy kokoelmaan Varhaisnykysuomen korpus: Innain. Helsinki: Kotimaisten kielten keskus. http:// kaino.kotus.fi/korpus/180o/meta/innain/schodlerin_physikki1856_rdf.xml (26.6.2018).

Silverstein, Michael 1979: Language structure and linguistic ideology. - Paul R. Clyne, William F. Hanks \& Carol F. Hofbauer (toim.), Elements. A parasession on linguistic units and levels s. 193-247. Chicago: Chicago Linguistic Society.

Solin, Anna 2006: Genre ja intertekstuaalisuus. - Anne Mäntynen, Susanna Shore \& Anna Solin (toim.), Genre - tekstilaji s. 72-95. Tietolipas 213. Helsinki: Suomalaisen Kirjallisuuden Seura.

Strellman, UrPU 2017: Tietokirjojen kustantamisen lähtökohdat ja näkymät. - Pirjo Hiidenmaa (toim.), T niin kuin tietokirjallisuus s. 119-132. Äidinkielenopettajain liiton vuosikirja. Helsinki: Äidinkielenopettajain liitto.

Sulkunen, Irma 2004: Suomalaisen Kirjallisuuden Seura 1831-1892. Helsinki: Suomalaisen Kirjallisuuden Seura.

Suomen kielen lautakunnan kannanotto 26.10.2018 = https://www.kotus.fi/ohjeet/suomen_kielen_lautakunnan_suosituksia/kannanotot/suomi_tarvitsee_pikaisesti_kansallisen_kielipoliittisen_ohjelman (8.11.2018).

Svensk sakprosa 1750-200o. Tutkimusprojekti. https://www.studentlitteratur.se/o.o.i.s/326 (9.11.2018).

Swales, John 1990: Genre analysis. English in academic and research settings. Cambridge: Cambridge University Press.

Thompson, John B. 1990: Ideology and modern culture. Stanford, CA: Stanford University Press.

Toury, Gideon 1995: The nature and role of norms in translation. - Gideon Toury, Descriptive translation studies and beyond s. 53-69. Benjamins Translation Library 4. Amsterdam: John Benjamins.

VehkAnen, MARJut 2015: Kieliopista kommunikaatioon. Suomi toisena ja vieraana kielenä -oppikirjat vuosina 1866-1953. Helsinki: Helsingin yliopisto. http://urn.fi/ URN:ISBN:978-951-51-1556-0.

WOOLARD, KATHRYN A. 1998: Introduction. Language ideology as a field of inquiry. - Bambi B. Schieffelin, Kathryn A. Woolard \& Paul V. Kroskity (toim.), Language ideologies. Practice and theory s. 3-47. New York: Oxford University Press.

Kirjoittajien yhteystiedot:

etunimi.sukunimi@helsinki.fi

Kirjoittajat ovat suomen kielen professoreita Helsingin yliopistossa. 